連載企画（安全な社会と表面科学 (4)

\section{交通事故の防止と被害軽減のための 交通事故統計分析}

\author{
西田泰 \\ 公益財団法人交通事故総合分析センター \\ 研究部 特別研究員兼研究第一課長 \\ 画 101-0064 東京都千代田区猿楽町 2-7-8
}

(2015 年 12 月 22 日受理)

\section{Traffic Accident Statistic Analysis for Accident Prevention and Reduction of Crash Severity}

Yasushi NisHidA

Research Specialist and Manager of Research Sec. 1 Institute for Traffic Accident Research and Data Analysis, 2-7-8 Sarugaku-cho, Chiyoda-ku, Tokyo 101-0064

(Received December 22, 2015)

\section{1.は じめに}

公益財団法人交通事故総合分析センター（以下，分析 センター）は，交通事故と人間，道路交通環境抒よび車 両に関する総合的な調查分析研究並びにその成果の提供 等を通じて，交通事故の防止と交通事故による被害の軽 減を眓ることにより, 安全, 円滑かつ秩序ある交通社会 の実現に寄与することを目的に, 平成 4 年 3 月に設立さ れ, 同年 6 月に道路交通法で定める交通事故調查分析七 ンターとしての指定を受け, 平成 24 年 4 月に公益財団 法人となっています。

分析センターは, 関係省庁から提供された交通事故や 道路交通に関する様々なデー夕を活用して分析を行うだ けでなく, 茨城県つくば市に設置したつくば交通事故調 查事務所が，つくば市および周辺地域で発生した交通事 故を対象に, 独自に収集した車両損壊, 救急救助や人の 傷害程度に関する詳細な交通事故例デー夕（以下，ミク ロデー夕）を使った分析も行っています。

ここでは，交通事故の防止や被害軽減のために，分析 センターが構築した交通事故統合データベース ${ }^{1)}$ との 分析事例を示すことで，交通事故の防止や被害軽隇のた めの交通事故統計分析について紹介します。

E-mail : nishida@itarda.or.jp

\section{2. 分析センターの事故分析と統合データベー ス}

分析センターが行う事故分析の特徴として二つあげる ことができます。一つは関係省庁から提供された統計デ ー夕を使った統計分析（マクロ分析）とミクロデータを 使ったミクロ分析を組み合わせた分析，そして，もう一 つは関係省庁から提供された交通事故等に関連するデー 夕を統合して構築した交通事故統合データベースを使っ た分析です。いずれの分析も他の機関が単独で害施する ことが難しく, 分析センターの意義はこのような分析が 行えることにあります。

\section{1 交通事故統合データベース}

Fig. 1 は，関係省庁等から提供されるデー夕と分析セ ンターが構築した統合データベースの関倸を示したもの です。交通事故データベースは，警察庁から提供された 交通事故統計デー夕の集計用に毎年構築するもので, 他 の統合データベースの元になります。交通事故・免許統 合データベースと交通事故・車両（・安全デバイス）統 合データベースは, 交通事故データベースの集計項目に 事故に関与した運転者の過去の違反や事故履歴等の情 報, あるいは関係車両の定員や最大積載量等の諸元情報 や ABS (Antilock Brake System) や ESC (Electronic Stability Control）等の安全デバイス情報を追加したもの で，毎年構築しています。

一方，全国道路・街路交通情勢調查をもとにした交通 事故・道路交通センサス統合データベース, 道路交通セ ンサス区間を交通事故分析のために交差点と単路に細分 化（イタルダ区間）して集計した交通事故・道路統合デ ータベースや, 免許・事故違反履歴統合データベース は，それぞれ道路状況や事故の情報あるいは免許種類や 過去の事故や検挙違反に関するデー夕を, 道路交通セン サス区間やイタルダ道路区間あるいは運転免許保有者を 単位にデータの追加更新をしています。このため, デー 夕数は前述の二つの統合データベースとは異なり, 免 許・事故違反履歴統合データベースでは事故や検挙違反 の履歴がない運転者を含めた全国 8200 万人の事故や検 挙違反に関する情報（多い運転者では数百項目以上）を 含む巨大なデータベースとなります。

\section{2 分析事例}

用途地域別・ゾーン 30 別の交通事故 ${ }^{2)}$

交通事故データベースの緯度・経度情報を使い事故発 生場所を特定することで細かな地域属性に着目した分析 ができます。埼玉県の平成 26 年中の交通事故を対象に, 


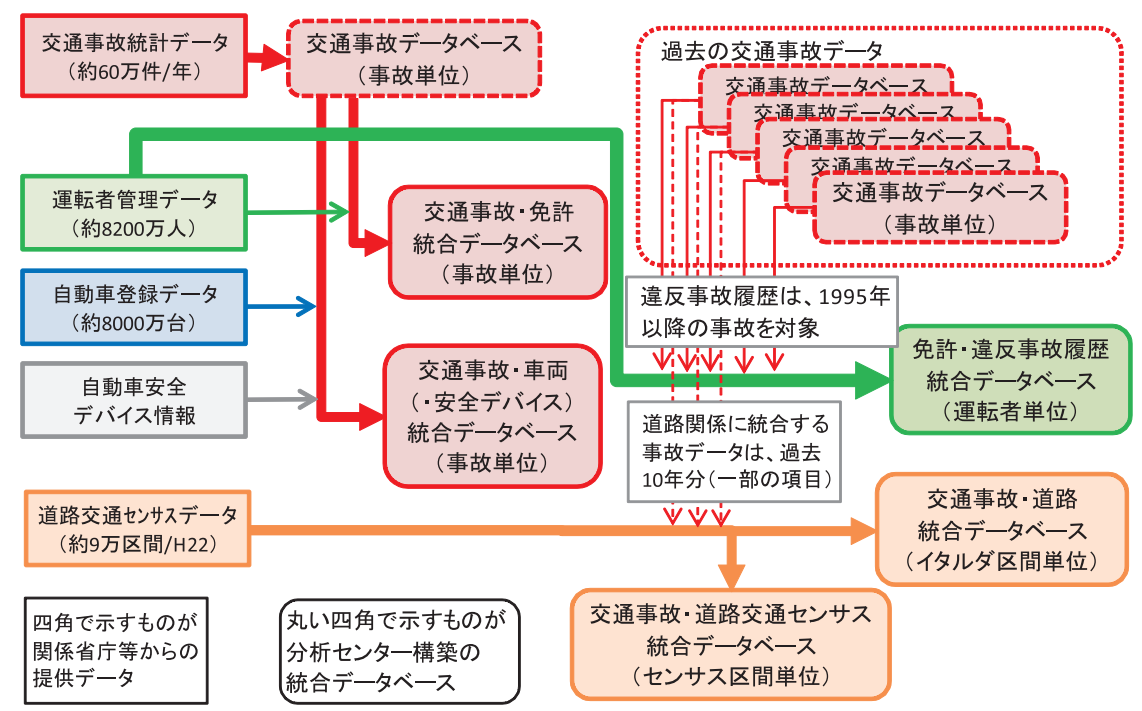

Fig. 1. (color online). Integrated Traffic Accident Database by ITARDA.

Table 1. (color online). Traffic accident rate by type of land use and with/without Zone 30 regulation.

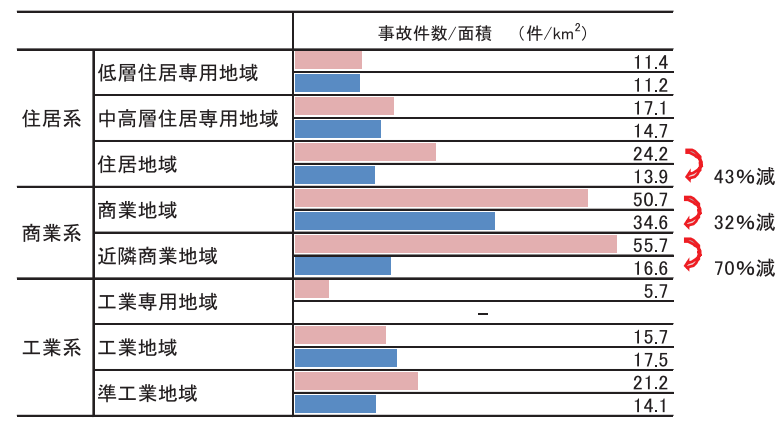

用途地域別, ゾーン 30（区間を決めて時速 30 キロの速 度規制等を実施するゾーン）別の単位面積当たりの事故 件数を算出した結果が Table 1 であり, 多くの用途地域 では, ゾーン 30 内での事故率が低くなっています（な お, 数值化した用途地域デー夕（国土数值情報）は国土 交通省国土政策局 HP から, ゾーン 30 規制デー夕は関 係機関から入手)。ゾーン 30 規制が事故防止に効果があ ると考えられます。

\section{事故・違反歴とその後の事故 ${ }^{3)}$}

免許・事故違反履歴統合データベースを使い, 2011 年中の男性運転者の事故当事者率（全運転者に占めるあ る 1 年間に事故を起こした運転者の割合）を過去 5 年間 の事故や検挙違反の経験回数別, 年齢層別にみると, 各 年齢層とも事故や検挙違反が多い者ほど, その後も事故 を起こす率が高くなっています（Fig. 2)。事故当事者や 交通違反の検挙者に対する対策の必要性が高いことがわ かります。

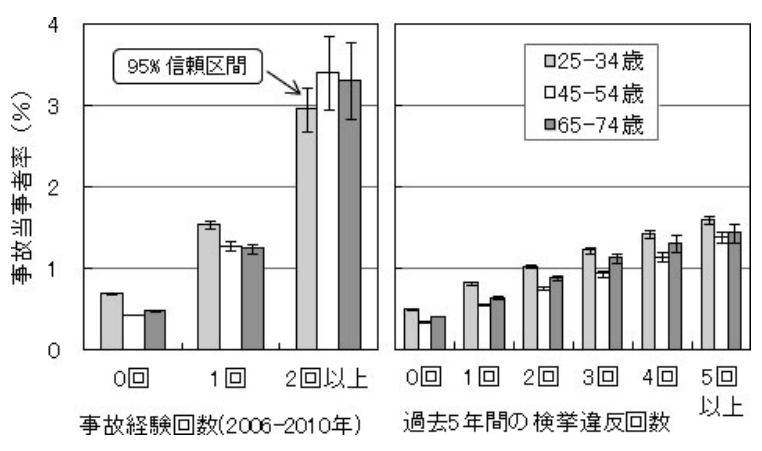

Fig. 2. Accident driver ratios by number of accidents/ violations on record in the last five years (Male drivers who caused traffic accidents in 2011 while driving private passenger cars).

\section{事故多発地点の特徵 ${ }^{4)}$}

交通事故・道路統合データベース（全国約 85 万箇所 のイタルダ区間）を対象に, 平成 24 年中の全国の事故 多発箇所上位 20 か所のうち単路区間を除く 19 箇所の特 徴を, 事故類型別分布に着目したクラスター分析で調べ た結果を Table 2 に示します。

追突事故が半数以上の交差点（A，B）は付近に高速 道路等との合流部があること, 追突と左折の多い交差点 （C，E）では立体交差点であるところが多くなっていま す。また, 右折事故の多い交差点 (D, F) は右折 2 車 線以上と直進 2 車線以上が交差する所が多いのですが, 左折事故の多い交差点 (C, E，F）では左折 2 車線であ る所はない等, 事故多発地点の特徵は様々であり, 場所 に応じた対策が必要と考えられます。 
Table 2. (color online). Grouping of accident black spots (top 19).

\begin{tabular}{|c|c|c|c|c|c|c|c|c|}
\hline & & \multirow[b]{2}{*}{ タイプ } & A & B & $\mathrm{C}$ & $\mathrm{D}$ & $E$ & $\mathrm{~F}$ \\
\hline & & & 追突 & 追突と他 & 追突と左折 & 追突と右折 & 左折と追突 & 右折と左折 \\
\hline & & 多発地点順位 & (1) (17) & (2) (12) (16) & (7) (13) (14) (18) & (5) (11) (20) (15) & (6) (10) (9) & (4) (8) (19) \\
\hline \multirow{6}{*}{ 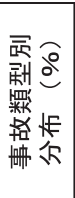 } & & 対車両 & 01 & $\begin{array}{lll}3 & 1 & 3 \\
\end{array}$ & $\begin{array}{llll}4 & 3 & 0 & 18 \\
\end{array}$ & $\begin{array}{llll}9 & 4 & 2 & 5 \\
\end{array}$ & $\begin{array}{lll}7 & 4 & 7 \\
\end{array}$ & $\begin{array}{lll}2 & 10 & 12 \\
\end{array}$ \\
\hline & 車 & 追突 & $98 \quad 94$ & $80 \quad 66 \quad 58$ & \begin{tabular}{|llll}
46 & 41 & 39 & 44
\end{tabular} & $\begin{array}{llll}37 & 39 & 33 & 32\end{array}$ & $\begin{array}{lll}24 & 24 & 21\end{array}$ & $\begin{array}{lll}16 & 19 & 23\end{array}$ \\
\hline & 両 & 右折 & & $\begin{array}{lll}8 & 18 & 3\end{array}$ & $\begin{array}{llll}7 & 13 & 18 & 10\end{array}$ & $\begin{array}{llll}20 & 27 & 23 & 33\end{array}$ & $\begin{array}{lll}14 & 10 & 6\end{array}$ & $\begin{array}{lll}41 & 35 & 24\end{array}$ \\
\hline & 相 & 左折 & & $\begin{array}{lll}0 & 2 & 10\end{array}$ & $\begin{array}{llll}20 & 16 & 27 & 18\end{array}$ & $\begin{array}{llll}19 & 14 & 15 & 16\end{array}$ & $\begin{array}{lll}37 & 39 & 33\end{array}$ & $31 \quad 20 \quad 24$ \\
\hline & 互 & 出会い頭 & & $\begin{array}{ll}9 & 20 \\
\end{array}$ & $\begin{array}{llll}7 & 8 & 0 & 1 \\
\end{array}$ & $\begin{array}{llll}6 & 10 & 17 & 5 \\
\end{array}$ & $\begin{array}{lll}5 & 13 & 13 \\
\end{array}$ & $\begin{array}{lll}3 & 13 & 4 \\
\end{array}$ \\
\hline & & の他 (車両単独含む) & 1 & 35 & $\begin{array}{lll}16 & 19 & 16 \\
\end{array}$ & $\begin{array}{lll}9 & 6 & 11 \\
\end{array}$ & $\begin{array}{lll}14 & 11 & 20 \\
\end{array}$ & $\begin{array}{lll}7 & 3 & 13 \\
\end{array}$ \\
\hline
\end{tabular}

Table 3. Odds ratio of relative accident rates by collision type, with/without a passenger and with/without ABS (All age male drivers, all road surfaces, daytime).

\begin{tabular}{ccccc}
\hline \multirow{2}{*}{ 事故類型 } & \multicolumn{2}{c}{ 同乗者なし } & \multicolumn{2}{c}{ 同乗者あり } \\
\cline { 2 - 6 } & オッズ比 & $(95 \%$ C.I.) & オッズ比 & $(95 \%$ C.I. $)$ \\
\hline 追 突 & $\mathbf{0 . 8 8}$ & $0.80-0.95$ & $\mathbf{0 . 7 5}$ & $0.61-0.90$ \\
出会い頭 & 0.99 & $0.90-1.08$ & 0.85 & $0.69-1.01$ \\
車両単独 & $\mathbf{0 . 7 1}$ & $0.54-0.88$ & 0.82 & $0.49-1.14$ \\
人対車両 & 1.10 & $0.95-1.26$ & 1.01 & $0.62-1.40$ \\
全事故類型 & 0.94 & $0.87-1.01$ & $\mathbf{0 . 8 5}$ & $0.74-0.96$ \\
\hline
\end{tabular}

太字は統計的に有意に, ABS 有の相対事故率が低い

\section{AHR（アクティブヘッドレスト） の効果 ${ }^{5)}$}

交通事故・車両統合データベース（2000～2004 年) を使い, AHR の効果を, 普通または軽自動車に追突さ れた車両（製造時期により AHR の有無が明確に分離で きる同じモデル）の乗員を対象に, AHR 装備有無別の 頸部無傷率を使い調べました。AHR を使用することに より頸部無傷率が, AHR 未使用時の 7.4\% から 16.7\%に 10 ポイント上がることが示されており，この傾向は性 別や年齿層別にみても見られるものです (図省略)。ア クティブヘッドレストによる頸部損傷の軽減効果が確認 されます。

\section{ABS の効果 ${ }^{6)}$}

交通事故・車両・安全デバイス統合データベース （2002２006 年）を使い, ABSの効果を, 運転者の性・ 年齢層, 同乗者の有無, 路面状態, 昼夜および事故類型 別に, ABS 装備車と非装着車の相対事故率の比（運転 方法の影響を受けずもっぱら運転頻度に比例すると考え られる停止中に追突される件数を分母, 対象とする事故 件数を分子として求めた事故率。走行距離当たりの事故 率に相当）を使って調べました。Table 3 は, 男性運転 者 (全年齢), 全路面状態, 昼間の条件で, 同乗者の有 無および事故類型別のオッズ比を示したものです。信頼 区間を考えると ABS に事故防止効果があると判定され るものは太字で示すケースとなりますが，追突事故の防 止効果は路面状態によらず確認され, デー夕数は少ない
ですがこの傾向は昼夜別や女性にも見られました（表省 略)。ABS には一定の事故防止効果があると考えられま す。

\section{3. おわりに}

交通事故統合データベースは既存の対策の事後評価だ けでなく, 計画中や将来の対策の事前評価等にも活用で きます。また, 医療データや保険デー夕等との統合デー タベースを構築することで, 交通事故や交通事故対策に 関する多面的議論が可能となります。

人, 道, 車の観点から様々な道路交通事故対策が実施 されていますが, 人々の社会・生活行動の多様化は, 従 来とは異なった形の道路交通問題を生じさせるようにも なっており, その問題解決には今まで以上に複数の学問 の境界領域での問題検討が必要となります。そんな状況 を考えると, 表面科学で蓄積されてきた概念や手法の活 用への期待も大きくなります。

\section{文 献}

1) 公益財団法人交通事故総合分析センター, 平成 26 年度事業報告書 (2014) p. 2. http://www.itarda.or.jp/ outline/disclosure/26houkoku.pdf

2) 下村静喜 : 交通事故リスクアセスメント〜生活道路 における交通安全対策， 公益財団法人交通事故総 合分析センター, 第 18 回交通事故・調査分析研究 発表会資料 (2015) 18_05.

3) Y. Nishida : Analyzing accidents and developing elderly driver-targeted measures based on accident and violation records, IATSS Research 39, 26 (2015).

4) 北野朋子, 田中祥夫 : 交通事故が多発する個所の特 徵と事故事例, 公益財団法人交通事故総合分析セン 夕一，第 17 回交通事故・調查分析研究発表会資料 (2014) p. 119.

5) 渡辺洋一: 車両属性・人的属性が追突事故頸部傷害 へ及ぼす影響, 財団法人交通事故総合分析センター, 第 9 回交通事故・調查分析研究発表会資料 (2006) p. 26.

6) Y. Nishida: The effect of ABS as a preventive safety device - the result of statistical analysis using integrated road traffic accident database, ESV2009 (2009) 09-0436. 